\title{
Successful IT/IS Projects in Healthcare: Evaluation of Critical Success Factors
}

\author{
Marius Schönberger ${ }^{1}$ and Andrejs Čirjevskis ${ }^{2}$ \\ BANKU Augstskola School of Business and Finance, Riga, Latvia, marius.schonberger@ba.Iv \\ RISEBA University of Business, Arts and Technology, Riga, Latvia, andrejs.cirjevskis@riseba.lv \\ Correspondence should be addressed to: Marius Schönberger; marius@schoenberger-home.de
}

Received date: 17 February 2017; Accepted date: 25 May 2017; Published date: 6 October 2017

Academic Editor: Patrik Pucer

Copyright (C 2017. Marius Schönberger and Andrejs Čirjevskis . Distributed under Creative Commons CCBY 4.0

\begin{abstract}
Information technology (IT) and information systems (IS) are an important economic factor for the healthcare sector and make a significant contribution to the improvement of products and services provided to patients. To remain competitive in the long term, companies from the healthcare industry are forced to permanently invest in new IT/IS systems. Therefore, this research discusses critical success factors and their interrelationships in relation to the implementation of IT/IS projects in the healthcare sector. Here, one focus of this study is the identification of general research for the investigation of critical success factors for the IT/IS implementations in the healthcare sector and the analysis of their findings and conclusions. As a result of this research, it can be stated that human errors and the complexity of the project are the main challenges in the implementation of IT/IS projects.
\end{abstract}

Keywords: Critical success factors, IT/IS projects, Project management, Healthcare

\section{Introduction}

Within the recent years, a great evolution in healthcare IT/IS systems has been identified in part as a result of the rapid development of new technologies (Schönberger, 2014; European Commission, 2007). However, technological innovation in healthcare is an important driver of cost growth (Barbash and Glied, 2010; Goyen and Debatin, 2009). Faced with strong competition and pressure to reduce costs across the healthcare sector, medical device manufacturers are banking on growth through breakthroughs in innovation and engineering (Stirling and Shehata, 2016). This is also confirmed by a study by Forbes and KPMG in 2015, in which companies were asked about their strategic priorities for the

Cite this Article as: Marius Schönberger and Andrejs Čirjevskis (2017)," Successful IT/IS Projects in Healthcare: Evaluation of Critical Success Factors", Journal of e-health Management , Vol. 2017 (2017), Article ID 956068, DOI: 10.5171/2017.956068 
next twelve to 24 months. According to this study, $35 \%$ of the surveyed companies reported the reduction of costs and $49 \%$ the development of new products (Stirling and Shehata, 2016). In this context, a recent trend in the healthcare industry is the implementation of modern IT/IS systems (Archer, 2016; Horvath, 2016; Varelis and Williams, 2016).

However, many IT/IS projects experience significant time and cost overruns (Sumner et al., 2006; Kaplan and Harris-Salamone, 2009; Jun et al., 2011). According to a survey of IBM (2008), only $40 \%$ of projects met schedule, budget and quality objectives (IBM, 2008). McKinsey reported in a study on large scale IT projects, that on average, these projects run $45 \%$ over budget and $7 \%$ over time, while delivering $56 \%$ less value than predicted (Bloch et al., 2012). Flyvbjerg and Budzier (2011) found similar facts: One out of six IT projects has an average cost overrun of $200 \%$ and a schedule overrun of $70 \%$ (Flyvbjerg and Budzier, 2011). Therefore, it is apparent, that there are significant contradictions between the reduction of costs and the introduction of new IT/IS systems. This statement is consistent with the results of the Forbes and KPMG survey, where $22 \%$ of the medical device manufacturers surveyed indicated that they will face major challenges in updating and aligning IT systems with the demand from the business (Stirling and Shehata, 2016).

The difficulties of implementation of IT/IS projects as well as assessing their performance are a research focus of the last decades (e.g. Gomes and Romão, 2015; Lueg and Lu, 2012; Santos et al., 2014; Kaplan and HarrisSalamone, 2009). Most research focuses on the identification of critical success factors or best practices that companies have to consider, in order to successfully complete the IT/IS projects (e.g. Hung et al., 2014; Ghazvini and Shukur, 2013; Koumaditis et al., 2013). The investigation of critical success factors in the context of the implementation of IT/IS projects is also requested by some researchers (e.g. Axelsson et al., 2011; Santos et al., 2014). Moreover, Medina et al. (2013) noted that existing methods used for the identification of critical success factors have a number of shortcomings, regarding the subjectivity of survey based studies and the complexity of internal and external factors (Medina et al., 2013).

With regard to the aforementioned key problems, this research addresses the question of how companies can reduce costs while investing in new IT/IS systems. As Santos et al. (2014) discovered that current research mainly focuses on information technology, engineering and software development but not yet on (public) health projects, this research focuses on the identification of critical success factors in the healthcare sector. Furthermore, as a questionnaire by the Radar Group (2012) concluded that one reason for IT project failure is a lack of transparency regarding dependencies (Radar Group, 2012; Wolf, 2015), this study also tries to evaluate the interrelationships between success factors for the implementation of IT/IS projects, in order to get a better transparency for project managers. Therefore, the following research questions are to be answered within the scope of this research:

1. What is the current state of research regarding the successful implementation of IT/IS projects in the healthcare sector?

2. Which concrete critical success factors for the implementation of IT/IS projects in the healthcare sector can be derived from the current research literature and what similarities, differences and interrelationships do they have?

3. What are the implications for future research on the use of critical success factors for implementing IT/IS projects in the healthcare sector?

This research is structured as follows: First, the necessary terminological basics are explained in section two. In section three, the related work according to this research topic 
is described. Therefore, a literature review was used to identify actual and contextspecific research. In section four, the findings of the literature review will be explained. Following this, the results are compared and evaluated with regard to the research questions in section five. Finally, this research concludes with a summary of findings and an outlook on further research activities in section six.

\section{Basic Terminology}

\section{Critical Success Factor}

Critical success factors were introduced by Rockart in 1979 as a guiding approach to help senior executives define their information needs in order to reach the objectives of the organization (Rockart, 1979; Axelsson et al., 2011; Gates, 2010). Since then, many researchers have focussed on describing different actions under which success is likely to occur (see chapter 'Introduction'), for example Boynton and Zmud (1984), Yew Wong (2005) or Morden (2016) who describe, that critical success factors have a significant effect on the achievement of enterprise objectives. In this context, Rockart (1979) identified four prime sources of critical success factors that reflect the way in which they contribute to the achievement of the business objectives: (1) the structure of the particular industry, (2) competitive strategy, industry position and geographic location, (3) environmental factors and (4) temporal factors (Rockart, 1979). This research focuses on strategic, environmental and temporal critical success factors for the successful implementation of IT/IS projects in the healthcare sector.

\section{Project Management and IT/IT Projects}

The Project Management Institute (PMI) defines the term "project management" as "the application of knowledge, skills, tools, and techniques to project activities to meet the project requirements" (PMI, 2013, p. 5). A similar definition is provided by ISO 21500 (2012) which describes project management as the "application of methods, tools, techniques and competencies to a project" (ISO, 2012, p. 4). In this context, a project can be described as a set of activities whose execution is unique, whose structure has a certain complexity, and whose defined objectives can be achieved in a given time and with given resources (Aichele and Schönberger, 2014). Project management includes the identification of requirements, the definition of clear objectives, the consideration of the competing requirements for time, quality and costs as well as the adaptation of specifications, plans and concepts to the different concerns and expectations of the various stakeholders (PMI, 2013). The management of IT projects differs from general project management mainly by the development, implementation or application of IT solutions in a specific business environment (Aichele and Schönberger, 2014). Here, development projects, such as strategy or innovation projects, and organizational projects, for example evaluation or implementation projects, can be distinguished (Wieczorrek and Mertens, 2008). This research focuses mainly on the implementation of IT/IS projects in the healthcare sector and is based on the definitions of the PMI (2013).

\section{Healthcare Industry in Europe}

Health is an important priority for Europeans who expect to receive appropriate healthcare (Eurostat, 2016; European Commission, 2007). In this context, the term "healthcare" comprises the sum of activities performed by institutions or individuals through the use of medical, paramedical and nursing knowledge and technology for the purpose of health protection and disease prevention, disease cure and reduction of premature mortality as well as the provision and management of public health (Eurostat, 2013). According to the research of MedTech (2015), around $7.5 \%$ of the total expenditure in health care is spent on medical technology in 2015. With approx. $30 \%$ of the worldwide expenditure on medi-

Marius Schönberger and Andrejs Čirjevskis (2017), Journal of e-health Management, DOI: $10.5171 / 2017.956068$ 
cal devices, Europe holds one of the biggest market for medical technology (Klein, 2016). Furthermore, 95\% of the 25,000 medical technology companies in Europe are SMEs employing more than 575,000 people (MedTech, 2015). Therefore, the healthcare sector and in particular the pharmaceutical industry are of economic importance (European Commission, 2017). In 2012, the EU pharmaceutical sector produced an output of 220 billion Euros and employed around 800,000 people (European Commission, 2014). Furthermore, the sector accounts for approximately $1.8 \%$ of the total manufacturing workforce and is one of the industries with the highest labour productivity (European Commission, 2017).

\section{Related work}

As described at the outset of this research, major challenges exist in the healthcare sector regarding the successful implementation of IT/IS projects (see chapter 'Introduction'). To investigate this problem, a literature review is used to determine existing research that has examined success factors for the IT/IS project implementation. Due to the heterogeneity of the companies established in the healthcare sector (see chapter 'Healthcare industry in Europe'), a complete overview of the literature is hardly realizable. Therefore, the aim of the review is to identify central literature on successful IT/IS project implementation, thus, within this chapter a general orientation of the literature will be presented.

The following literature databases were searched for literature research: Google Scholar, Ebsco Academic Search, Scopus, Sciencedirect, Sage Journals and Directory of Open Access Journals. The following keywords have been used to search through the databases: IT Project, IS Project, Successful, Success Factors, Project Success, Implementation, Introduction, Adoption and Healthcare. Finally, for the collection of other relevant literature, the bibliographies of the already determined results were analysed. Below, the contents of the identified literature sources, as shown in Table 1, are briefly summarised.

Table 1: Related work focusing on critical success factors for IT/IS implementations in the healthcare sector.

\begin{tabular}{|l|l|l|l|l|}
\hline Author(s) & Year & Methodology & Research topic & $\begin{array}{l}\text { Focused coun- } \\
\text { try(ies) }\end{array}$ \\
\hline Abouzahra & 2011 & 4-year study & $\begin{array}{l}\text { Causes of failure in healthcare IT } \\
\text { projects }\end{array}$ & Saudi Arabia \\
\hline Axelsson et al. & 2011 & $\begin{array}{l}\text { Literature review, } \\
\text { semi-structured } \\
\text { interviews and case } \\
\text { study }\end{array}$ & $\begin{array}{l}\text { Best practices and critical success } \\
\text { factors for IT implementation }\end{array}$ & Sweden \\
\hline $\begin{array}{l}\text { Ghazvini and } \\
\text { Shukur }\end{array}$ & 2013 & $\begin{array}{l}\text { Literature review } \\
\text { factors of electronic healthcare } \\
\text { systems }\end{array}$ & Malaysia \\
\hline Gomes et al. & $2016 a$ & $\begin{array}{l}\text { Questionnaire and } \\
\text { guided interview }\end{array}$ & $\begin{array}{l}\text { Maturity models and project suc- } \\
\text { cess in healthcare }\end{array}$ & Portugal \\
\hline Hung et al. & 2014 & $\begin{array}{l}\text { Literature review, } \\
\text { online survey and } \\
\text { regression analysis }\end{array}$ & $\begin{array}{l}\text { Critical success factors for the } \\
\text { implementation of integrated } \\
\text { healthcare information systems }\end{array}$ & Taiwan \\
\hline
\end{tabular}

Marius Schönberger and Andrejs Čirjevskis (2017), Journal of e-health Management, DOI: $10.5171 / 2017.956068$ 


\begin{tabular}{|l|l|l|l|l|}
\hline $\begin{array}{l}\text { Kaplan and } \\
\text { Harris-Salamone }\end{array}$ & 2009 & $\begin{array}{l}\text { Literature review and } \\
\text { workshop }\end{array}$ & Success and failure of health IT & United States \\
\hline Koumaditis et al. & 2013 & $\begin{array}{l}\text { Literature review and } \\
\text { case study }\end{array}$ & $\begin{array}{l}\text { Critical success factors for the } \\
\text { implementation of service ori- } \\
\text { ented architecture }\end{array}$ & $\begin{array}{l}\text { Greece and } \\
\text { Portugal }\end{array}$ \\
\hline Santos et al. & 2014 & Literature review & $\begin{array}{l}\text { Model for success factors for } \\
\text { public health projects }\end{array}$ & Portugal \\
\hline $\begin{array}{l}\text { Vagelatos and } \\
\text { Sarivougioukas }\end{array}$ & 2001 & $\begin{array}{l}\text { Implementation pro- } \\
\text { ject }\end{array}$ & $\begin{array}{l}\text { Critical success factors for IT } \\
\text { implementation }\end{array}$ & Greece \\
\hline
\end{tabular}

\section{A. Abouzahra (2011). Causes of failure in healthcare IT projects.}

The research by Abouzahra based on a four years' survey conducted in six of the largest hospitals in Saudi Arabia and studying 52 healthcare IT projects between 2007 and 2011. The study aims to compare causes of failure in healthcare IT projects by reviewing the project documentations. As the results show, the main causes of failure being unclear scope, unidentified risks and stakeholders, communication and other factors. The study concludes by providing guidelines that should help in increasing the success rate of IT projects (Abouzahra, 2011).

\section{B. Axelsson et al. (2011). Analyzing best practice and critical success factors in a health information system case: Are there any shortcuts to successful IT implemen- tation?}

Axelsson et al. discussed critical success factors and best practice in relation to IT implementation in the healthcare sector. Therefore, the authors had conducted a qualitative and interpretive study of the implementation process of a health information system in a Swedish public health provider organisation in 2010. The data collection involved interviews, studies of documents, field work and systems studies. The case study indicated

that the implementation of an IS system, that is based on best practices solutions for healthcare, is not automatically creating success by following critical success factors. The study ends with the finding that the results are valid not only for health information systems but also for any other IT/IS project in the private or public sector (Axelsson et al., 2011).

\section{Ghazvini and Shukur (2013). Security challenges and success factors of elec- tronic healthcare system}

The aim of the research by Ghazvini and Shukur was to explore and analyse the current state of e-health systems security and privacy of patient records. Therefore, the focus was on developing a framework for information security in order to protect electronic patient record. The authors conducted a literature review to identify relevant studies on the research focus. A total of twelve relevant research studies were analysed in relation to the research questions. As the results show, human error is the most challenging issue regarding the implementation of e-health systems (Ghazvini and Shukur, 2013).

\section{Gomes et al. (2016a). Organisational maturity and project success in health- care: The mediation of project manage- ment.}

The focus of the research by Gomes et al. was to design a framework for different management approaches in order to strengthen the outcomes of investments for IT/IS in the health sector. Therefore, the authors developed hypotheses that are based on a litera- 
ture review. These hypotheses were examined using a questionnaire and guided interviews. The chosen sample included seven hospitals in Portugal. The analysis of the questionnaires and interviews showed that the correct appropriation of technology and the use of project management techniques are facilitators in achieving greater success from project outcomes (Gomes et al., 2016a).

\section{E. Hung et al. (2014). Critical success fac- tors for the implementation of integrated healthcare information systems projects: An organizational fit perspective.}

The study by Hung et al. investigated the relationship between organizational fit factors and critical success factors for the implementation of integrated health information systems in hospitals. Based on a literature review, the authors conducted hypotheses in order to explain direct effects of organizational fit on the success of integrated health information systems. An online survey, involving 53 hospitals from Taiwan, was used to collect data. Following this, the regression analysis was used to assess the relationships. The findings provided a roadmap for hospitals to capitalize on the organizational fit and the critical success factors in order to implement successful IS projects (Hung et al., 2014).

F. Kaplan and Harris-Salamone (2009). Health IT success and failure: Recommendations from literature and an AMIA workshop.

Kaplan and Harris-Salamone describe the implementation of a workshop for the identification of success factors for health information technology projects. Over 60 persons and experts out of the US healthcare sector participated at the workshop and discussed aspects of project management that are necessary for the success of implementing health information systems. As the results of the workshop show, problems exist due to socio- logical, cultural and financial issues (Kaplan and Harris-Salamone, 2009).

\section{G. Koumaditis et al. (2013). SOA imple- mentation critical success factors in healthcare.}

The aim of the research by Koumaditis et al. was to identify critical success factors for the implementation of service oriented architectures in the healthcare organizations. Therefore, the authors reviewed the literature and identified critical success factors in relation to the research focus. These factors were compared and synthesised to a conceptual model of critical success factors for the implementation of service oriented architecture solutions. The conceptual model was tested in the practical arena using a case study strategy. The research concludes with the finding that the conceptual model can support practitioners and researchers in the implementation of similar IS projects (Koumaditis et al., 2013).

\section{H. Santos et al. (2014). Project Manage- ment success in health - the need of addi- tional research in public health projects.}

The research by Santos et al. focused on project management success and the need of developing a model of success factors for public health projects. Based on a literature review, the main perspectives about success criteria and success factors were described. Following this, the authors discussed the advantages of creating a model of success factors for public health projects. As the results show, additional research is needed to improve knowledge about success factors in public health projects (Santos et al., 2014).

I. Vagelatos and Sarivougioukas (2001) Critical success factors for the introduction of a clinical information system.

Vagelatos and Sarivougioukas discussed critical success factors and issues that were identified during the implementation of a

Marius Schönberger and Andrejs Čirjevskis (2017), Journal of e-health Management, DOI: $10.5171 / 2017.956068$ 
clinical information system in a Greek hospital. The research was based on the findings of a clinical information system project that was implemented in the hospital in 1998. Success factors, which were identified during the deployment of the project, were evaluated by the authors. The results of the research verified that critical issues in the implementation of IS projects are social and organizational and not solely technical (Vagelatos and Sarivougioukas, 2001).

\section{Research findings}

The results of the identified research contributions have some similarities: The majority of the authors describe critical success factors for the implementation of IT/IS projects (Axelsson et al., 2011; Ghazvini and Shukur, 2013; Hung et al., 2014; Koumaditis et al., 2013; Vagelatos and Sarivougioukas, 2001). The other authors, on the one hand, focus on causes of success and failures in IT projects (Abouzahra, 2011; Kaplan and HarrisSalamone, 2009), and on the other hand, investigate models for maturity and success factors (Gomes et al., 2016a; Santos et al., 2014). In most cases, a literature review was conducted for data collection (Axelsson et al., 2011; Ghazvini and Shukur, 2013; Hung et al., 2014; Kaplan and Harris-Salamone, 2009; Koumaditis et al., 2009; Santos et al., 2014). Furthermore, paper based or online questionnaires, guided interviews with experts and case studies helped to collect and verify necessary data (Axelsson et al., 2011; Gomes et al., 2016a; Hung et al., 2014; Koumaditis et al., 2009). Moreover, the literature sources focus mainly on the European area (Axelsson et al., 2011; Gomes et al., 2016a; Koumaditis et al., 2009; Santos et al., 2014; Vagelatos and Sarivougioukas, 2001).
In order to answer the second research question (see chapter 'Introduction'), the literature listed in Table 1 was analysed more precisely and, thus, further similarities were found. The results of the research conducted by Abouzahra (2011), Hung et al. (2014) and Koumaditis et al. (2013) provide guidelines and recommendations for the successful implementation of IT/IS projects in hospitals. Ghazvini and Shukur (2013), Kaplan and Harris-Salamone (2009) and Vagelatos and Sarivougioukas (2001) conclude that problems in the implementation of IT/IS projects exist due to social, organizational or financial issues and not solely due to technical issues. Finally, Axelsson et al. (2011) and Koumaditis et al. (2013) determined that the identified critical success factors are valid not only for IT/IS projects in the healthcare area but also for any other IT/IS project in the private or public sector.

Furthermore, based on the detailed analysis, 33 critical success factors could be identified within the literature. These success factors were summarized and compared to the findings of the collected literature. As a result, again commonalities could be determined (see Appendix 1). Due to the fact that critical success factors are criticized as offering oversimplified solutions that are difficult to realize in practice (Axelsson et al., 2011; Berg, 2001; Wagner et al., 2006) and project management approaches may differ in each project (Gomes et al., 2016a; Gomes et al., 2016b), only the top ten critical success factors identified in the literature will be chosen for further research (see Table 2). As these ten factors have been most frequently mentioned in the identified literature, it is highly probable that these factors can be implemented by companies in the healthcare sector and are also implemented in most project management approaches. The top ten critical success factors are briefly explained below.

Marius Schönberger and Andrejs Čirjevskis (2017), Journal of e-health Management, DOI: $10.5171 / 2017.956068$ 
Table 2: Top ten critical success factors named in the identified literature sources

\begin{tabular}{|l|l|l|}
\hline Success Factors & $\begin{array}{l}\text { Total named in } \\
\text { the literature } \\
\text { sources }\end{array}$ & Rank \\
\hline Team & 6 & 1 \\
\hline Clear goals / Scope & 5 & 2 \\
\hline Communication & 5 & 3 \\
\hline Experience / Education & 5 & 4 \\
\hline $\begin{array}{l}\text { Project planning / Long-term plan- } \\
\text { ning }\end{array}$ & 5 & 5 \\
\hline Risk Management & 5 & 6 \\
\hline Complexity & 4 & 7 \\
\hline Process alignment & 4 & 8 \\
\hline Roles & 4 & 9 \\
\hline Top management support & 4 & 10 \\
\hline
\end{tabular}

Under the factor "team" the team members and their different skills and expertise are subsumed (Koumaditis et al., 2009). The factor "clear goals / scope" means that there is a high level of understanding of the size of the project and its objectives (Axelsson et al., 2011). The formulation and adherence to clear communication rules are summarized under the factor "communication" (Abouzahra, 2011). The factor "experience / training" refers to the availability of a wide range of experience about the project, the processes and the environment during the implementation of the IT/IS project (Koumaditis et al., 2009). The term "project planning / long-term planning" is used to describe the project scope, objectives, staff and roles of the project as well as the activities to be processed after the implementation (Koumaditis et al., 2009). The identification and documentation of risks that may arise before, during and after the implementation of the IT/IS project is summarized under the factor "risk management" (Abouzahra, 2011).

Larger projects with several stakeholders, different ways to achieve objectives or other barriers to the successful implementation of the project, such as geographic obstacles, laws or linguistic problems, are summarized under the factor "complexity" (Ghazvini and Shukur, 2013; Koumaditis et al., 2009). The factor "process alignment" defines the need to align the business strategy with the business processes and the implementation of the IT/IS project (Koumaditis et al., 2009). A wide range of experiences about the project and the objectives, tasks and activities for a specific project member are summarized under the factor "Role" (Axelsson et al., 2011) and, thus, indicating a parallel to the factor "experience / education". The factor "top management support" means that financial, personnel or other support from the top management can have an impact on the project outcomes (Hung et al., 2014).

Finally, to answer the second research questions completely, the interrelationships between each success factor were examined in a further step. For this purpose, a functional analysis was conducted according to the approach by Adunka (2010a and 2010b) and Thurnes et al. (2015) that is originally as-

Marius Schönberger and Andrejs Čirjevskis (2017), Journal of e-health Management, DOI: $10.5171 / 2017.956068$ 
signed to the TRIZ methodology (theory of inventive problem solving) and is normally used in the technical environment. Therefore, in a first step, an interaction matrix was developed that helped to determine which success factors interact with one another. To build up an interaction matrix, the success factors were entered into a table with identical order in a header row and header column. Following this, each cell of the matrix was analysed and in case of an interaction of the factors a "+" symbol was entered into the cell. If there were no interaction, a "-" symbol was entered. For example, a team must determine communication rules to define goals, tasks, deadlines or responsibilities within the project (interaction between team and communication: "+"), but the communication rules have no influence on the project planning (interaction between project planning and communication: "-"). The whole interaction matrix is shown in Appendix 2.

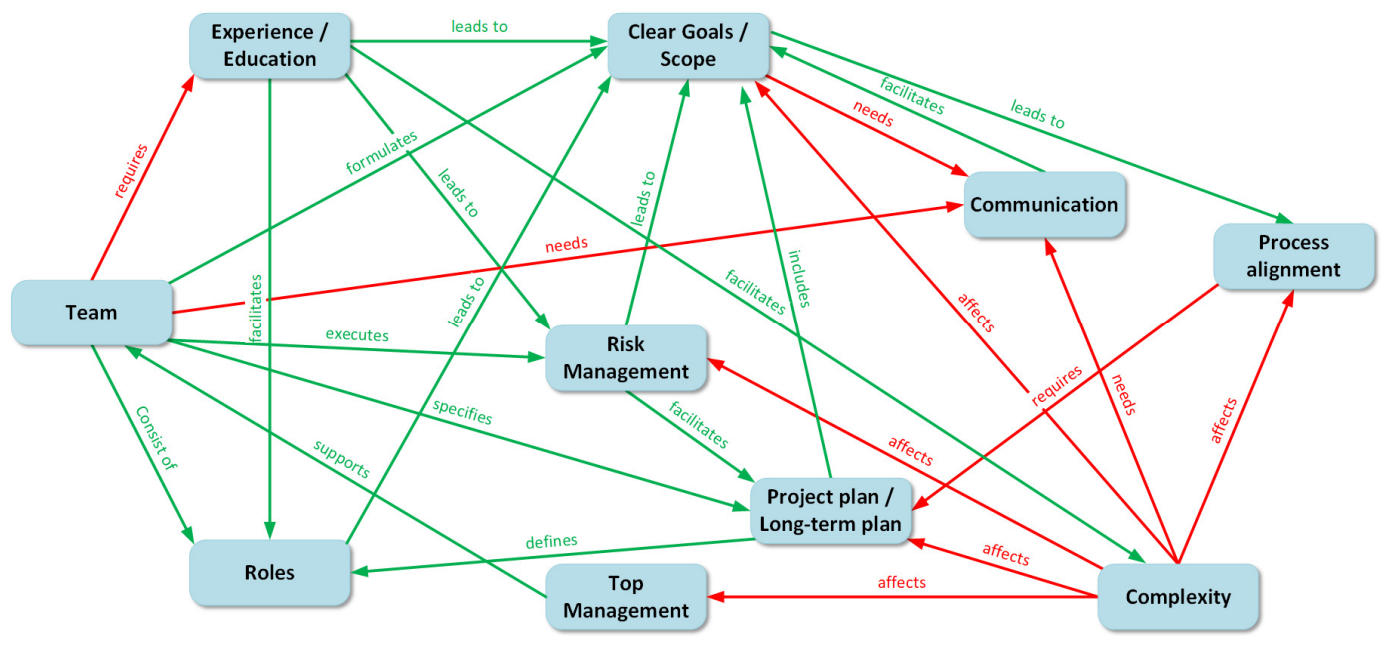

Figure 1: Function model of critical success factors for IT/IS project implementations in the healthcare sector.

In a second step, a function model was developed, which served to graphically represent the interrelationships between the success factors marked with a "+" symbol. As shown in Figure 1, the success factors are represented as rectangles and the relationships between the factors as arrows. In addition to the interaction matrix, useful and harmful relationships were determined. Useful relationships (green) between two success factors may change the project success in the desired direction, while harmful relationships (red) may change the project success in

an unwanted direction. Any relationship described by a negative verb, such like "affects" or "requires", was classified as a harmful relationship. For example, a high level of experience and education of the project staff leads to the definition of clear project objectives (useful). However, a high complexity of the project can have a negative impact on the definition of clear project objectives (harmful). In this context, 16 useful and ten harmful relationships were identified (see Figure 1).

\section{Conclusions and hypotheses}

Figure 1 shows that the critical success factors "team" and "complexity" have the greatest impact on the other success factors and, thus, on the overall success of projects. While

Marius Schönberger and Andrejs Čirjevskis (2017), Journal of e-health Management, DOI: $10.5171 / 2017.956068$ 
the factor "team" has predominantly useful relationships with the other success factors, the factor "complexity" has only harmful relationships. The complexity affects, for example, risk management or project planning and requires clear communication rules to be handled. Therefore, the team must define clear communication rules before implementing the project in order to be able to conduct a conscientious project planning and risk assessment. The functional model also shows that the experience of the project staff has a significant influence on the project success. Thus, it can be assumed that due to the experience and education of the project staff, the complexity of a project can be better handled. The results of this research correspond with the results of other current research. Marzagão and Carvalho (2016), Niazi et al. (2016), Ghazvini and Shukur (2013) and Axelsson et al. (2011) also confirmed that human errors and the complexity of the project are the main challenges in the implementation of IT/IS projects, and the execution of appropriate training can increase the abilities of the project staff. Moreover, a survey conducted by IBM in 2008 already identified that the underestimation of complexity was listed as a factor in $35 \%$ of the projects (IBM, 2008).

The identified critical success factors and their interrelationships between each other (see Figure 1) make it possible to formulate hypotheses for further quantitative studies. Furthermore, the third research question is answered by means of the following hypotheses.

- H1: The higher the experience / education of the team, the higher is the project success.

- H2: The clearer the roles within the team are, the higher is the project success.

- H3: The better the team roles have been formulated, the easier the project objectives can be achieved.
Hypotheses $\mathrm{H} 1$ to $\mathrm{H} 3$ are based on the finding that the internal factors in project failure involving the project team dynamics represent a large cause for the project failure than external factors (Abouzahra, 2011; Xiangnan et al., 2010; Ghazvini and Shukur, 2013). Furthermore, Koumaditis et al. report that IT/IS projects fail when there is a non-balanced team (Koumaditis et al., 2013).

- H4: The clearer the project objectives, the higher the project success.

- H5: The clearer the project objectives are, the better the project process can be aligned.

- H6: The better the project objectives are communicated, the higher is the project success.

Hypotheses $\mathrm{H} 4$ to $\mathrm{H} 6$ are based on the finding that the definition of clear project objectives and their communication within the project team have a decisive influence on the success of the project (Abouzahra, 2011; Gomes et al., 2016a; Hung et al., 2014; Koumaditis et al., 2013).

- H7: The better the project was planned by the team, the higher is the project success.

- H8: The better the project process can be aligned, the better the project plan.

- H9: The better the project planning is, the better the project objectives can be achieved.

- H10: The better the project planning is, the better the project roles are defined.

From a project management point of view, hypotheses $\mathrm{H} 7$ to $\mathrm{H} 10$ based on the findings that the main factors to cause project failures are unclear objectives as well as communication problems and risk management problems (Abouzahra, 2011; Gomes et al., 2016a; Hung et al., 2014; Koumaditis et al., 2013; Axelsson et al., 2011). According to Abouzahra, unclear scope is one of the big-

Marius Schönberger and Andrejs Čirjevskis (2017), Journal of e-health Management, DOI: $10.5171 / 2017.956068$ 
gest causes behind IT/IS project failures (Abouzahra, 2011).

- H11: The more controlled the communication within the team is, the higher is the project success.

- H12: The better the communication within the project is, the better the project objectives can be achieved.

Hypotheses H11 and H12 are based on the finding that communication challenges can lead to problems in the identification of project requirements, the definition of unambiguous project objectives and the control of the project (Abouzahra, 2011; Kaplan and Harris-Salamone, 2009; Gomes et al., 2016a).

- H13: The higher the experience / education of the project staff is, the better the project objectives can be achieved.

- H14: The higher the experience / education of the project staff is, the better the risk for the project can be determined.

- H15: The higher the experience / education of the project staff is, the easier it is to understand the complexity of the project.

- H16: The higher the experience / education of the project staff is, the easier it is to execute the project role.

Research shows that the capability of the project staff, enterprise system experience and project management skills have an effect on the success of the implementation of an IT/IS project (Hung et al., 2014; Kaplan and Harris-Salamone, 2009; Koumaditis et al., 2013; Ghazvini and Shukur, 2013; Axelsson et al., 2011).

- H17: The better the risk for the project is determined, the better the project objectives can be defined.
- H18: The better the risk for the project is determined, the better the project can be planned.

- H19: The better the risk was determined by the team, the higher is the project success.

Hypotheses H17 to H19 are based on the finding that the identification and assessment of project, operational and financial risks must be permanently verified during the implementation of the project in order to ensure a subsequent project success (Abouzahra, 2011; Kaplan and HarrisSalamone, 2009; Koumaditis et al., 2013).

- H20: The higher the complexity of the project is, the lower the support by the top management.

- H21: The higher the complexity of the project is, the more difficult is the project planning.

- H22: The higher the complexity of the project is, the more difficult is the determination of the risk of the project.

- H23: The higher the complexity of the project is, the more difficult is the determination of clear project objectives.

- H24: The higher the complexity of the project is, the more communication is required for project success.

- H25: The higher the complexity of the project is, the worse the project process can be aligned.

Although the success factor "complexity" is only recommended by a few authors (Santos et al., 2014; Ghazvini and Shukur, 2013; Koumaditis et al., 2013; Kaplan and HarrisSalamone, 2009), it is apparent that the factor "complexity" affects almost all other success factors, thus mastering complexity is crucial for project success (Abouzahra, 2011; Koumaditis et al., 2013; Ghazvini and Shukur, 2013). 
- H26: The better the top management supports the project team, the higher is the project success.

Hypothesis $\mathrm{H} 26$ is based on the finding that the support of top management in the case of complex and risky projects is decisive for the project success (Axelsson et al., 2011; Koumaditis et al., 2013; Gomes et al., 2016a; Hung et al., 2014).

\section{Limitation and outlook}

This study has tried to close the research gap initially mentioned by using a qualitative study. Based on a literature analysis, critical success factors were identified for the successful implementation of IT/IS projects in the healthcare sector. For a detailed analysis, the interrelationships between the identified success factors were evaluated. In summary, it should be noted that the literature often named identical success factors for the successful IT/IS implementation, and, thus, the literature collected on the subject area is very homogeneous. Based on the results of the literature review and the hypotheses developed and discussed in this research, the need for further research in the field of critical success factors in healthcare IT/IS projects, according to Santos et al. (2014), is demonstrated.

This research has several minor limitations. With regard to the consideration of the interrelationships between the critical success factors, only the top ten factors were considered. The inclusion of all identified success factors would possibly lead to further findings. Furthermore, the results obtained from this research would gain further in quality through a wider literature analysis with regard to the expansion of the search area.

Finally, this work provides several connecting factors for further research work. The hypotheses developed in this study provide a basis for future research to explore the iden- tified critical success factors and to examine their predictability for the success of IT/IS projects in the healthcare industry. Furthermore, this work could serve as the basis for the development of an approach to the use of critical success factors for IT/IS implementations. Further research can also deal with examining the identified success factors for use in other IT projects as well as in other industries.

\section{References}

1. Abouzahra, M. (2011) 'Causes of failure in healthcare IT projects,' 3rd International Conference on Advanced Management Science, Vol. 19, Singapore: IACSIT Press, 46-50.

2. Adunka, R. (2010a) 'Function analysis for electronic products,' Proceedings of the 10th ETRIA World TRIZ Future Conference, November 3-5, Bergamo, Italy, 165-171.

3. Adunka, R. (2010b), Begleitbuch zum TRIZ-Basiskurs, German MATRIZ Level 1 Training Course, 03/2015.

4. Aichele, C. and Schönberger, M. (2014), IT-Projektmanagement. Effiziente Einführung in das Management von Projekten. Wiesbaden: Springer.

5. Archer (2016), 'Medical device development trends in 2016,' 04 January 2016. [Online], [Retrieved January 17, 2017], http://www.archer-

soft.com/en/blog/medical-devicesdevelopment-trends-2016.

6. Axelsson, K.; Melin, U. and Söderström, F. (2011), 'Analyzing best practice and critical success factors in a health information system case: Are there any shortcuts to successful IT implementation?' 19th European Conference on Information Systems (ECIS) 2011. June 9-11, Helsinki, Finland, 2157-2168.

7. Barbash, G. I. and Glied, S. A. (2010), 'New technology and health care costs - the case of robot-assisted surgery,' New England Journal of Medicine, Vol. 363, Issue 8, 701-704.

8. Berg, M. (2001), 'Implementing information systems in health care organizations: myths and challenges,' International Journal of Medical Informatics, 64, 143-156. 
9. Bloch, M.; Blumberg, S. and Laartz, J. (2012) 'Delivering large-scale IT projects on time, on budget, and on value,' [Online], [Retrieved January 17, 2017], http://www.mckinsey.com/businessfunctions/digital-mckinsey/ourinsights/delivering-large-scale-it-projectson-time-on-budget-and-on-value. 10. Boynton, A. C. and Zmud, R. W. (1984) 'An assessment of critical success factors,' Sloan management review, Vol. 25; Issue 4, 17-27.

11. European Commission (2007) 'Together for health: A strategic approach for the EU 2008-2013,' White Paper, COM(2007) 630 final. Brussels, 23 November 2007.

12. European Commission (2014) 'Pharmaceutical industry: A strategic sector for the European economy,' Commission staff working document, SWD(2014) 216 final/2, 1st August 2014, Brussels.

13. European Commission (2017) 'Healthcare industries,' [Online], [Retrieved January 17, 2017],

http://ec.europa.eu/growth/sectors/healthc are_de.

14. Eurostat (2013) 'Glossary: Healthcare,' [Online], [Retrieved January 17, 2017], http://ec.europa.eu/eurostat/statisticsexplained/index.php/Glossary:Healthcare. 15. Eurostat (2016) 'Health statistics introduced,' [Online], [Retrieved January 17, 2017],

http://ec.europa.eu/eurostat/statisticsex-

plained/index.php/Health_statistics_introduc ed.

16. Flyvbjerg, B. and Budzier, A. (2011) 'Why Your IT Project Might Be Riskier than You Think,' Harvard Business Review, Vol. 89, No. 9, 601-603.

17.Gates, L. P. (2010) 'Strategic planning with critical success factors and future scenarios: An integrated strategic planning framework,' No. CMU/SEI-2010-TR-037, November 2010, Report of Software Engineering, Carnegie Mellon University.

18. Ghazvini A. and Shukur, Z. (2013) 'Security challenges and success factors of electronic healthcare system,' Procedia Technology, Vol. 11, 212-219.
19. Gomes, J. and Romão, M. (2015) 'Achieving project success through alignment with organizational strategy: Balanced Scorecard approach,' Proceedings of 8th IADIS International Conference-Information's Systems 2015, March 14-16, Madeira, Portugal, 81-88. 20.Gomes, J.; Romão, M. and Carvalho, H. (2016a) 'Organisational maturity and project success in healthcare: The mediation of project management,' Proceedings of the 9th International Joint Conference on Biomedical Engineering Systems and Technologies (BIOSTEC 2016), Vol. 5, 359-364.

21.Gomes, J.; Romão, M. and Carvalho, $\mathrm{H}$. (2016b) 'Successful IS/IT projects in healthcare: Pretesting a questionnaire,' Procedia Computer Science, 100, 375-382.

22. Goyen, M. and Debatin, J. F. (2009) 'Healthcare costs for new technologies,' European Journal of Nuclear Medicine and Molecular Imaging, March 2009, Vol. 36, Supplement 1,139-143.

23. Horvath, K. (2016) '2016 trends and challenges for medical technology providers,' [Online], [Retrieved January 17, 2017], https://intland.com/blog/medical/2016-

trends-and-challenges-for-medicaltechnology-providers/.

24.Hung, S. Y.; Chen, C. and Wang, K. H. (2014) 'Critical success factors for the implementation of integrated healthcare information systems projects: An organizational fit perspective,' Communications of the Association for Information Systems, Vol. 34, No. 1, Article 39, 775-796.

25.IBM (2008) 'Making change work,' [Online], [Retrieved January 17, 2017], http://www-

935.ibm.com/services/us/gbs/bus/pdf/ gbe03100-usen-03-making-change-work.pdf. 26. ISO (2012) 'Guidance on Project Management,' ISO 21500:2012(E), ICS 03.100.40, Geneva.

27.Jun, L.; Qiuzhen, W. and Qingguo, M. (2011) 'The effects of project uncertainty and risk management on IS development project performance: A vendor perspective,' International Journal of Project Management, Vol. 29, Issue 7, 923-933. 
28. Kaplan, B. and Harris-Salamone, K. D. (2009) 'Health IT success and failure: Recommendations from literature and an AMIA workshop,' Journal of the American Medical Informatics Association, Vol. 16, No. 3, 291299.

29. Klein, T. (2016) 'The medtech revolution: The European medical technology industry,' In: Martorell, J. M.; Barberà, A.; Farré, A.; Bertalan, M.; Norah, G.; Biosca, I.; Estrada, G.; Klein, T. and Shahin, T. (eds.) 'Catalonia life sciences and healthcare outlook,' April 2016, 80-91, [Online], [Retrieved December 27, 2016], http://informe.biocat.cat/wpcontent/themes/santi/pdf/informe/ PDFinforme-ENG.pdf

30. Koumaditis, K.; Themistocleous, M. and Rupino Da Cunha, P. (2013) 'SOA implementation critical success factors in healthcare,' Journal of Enterprise Information Management, Vol. 26, No. 4, 343-362.

31. Lueg, R. and Lu, S. (2012) 'Improving efficiency in budgeting - An interventionist approach to spreadsheet accuracy testing,' Problems and Perspectives in Management, Vol. 10, Issue 1, 32-41.

32. Marzagão, D. S. L. and Carvalho, M. M. (2016) 'Critical success factors for Six Sigma projects,' International Journal of Project Management, Vol. 34, Issue 8, 1505-1518.

33. Medina, L. A.; Jankovic, M.; Kremer, G. E. O. and Yannou, B. (2013) 'An investigation of critical factors in medical device development through Bayesian networks,' Expert Systems with Applications, Vol. 40, Issue 17, 7034-7045.

34. MedTech (2015), 'The European Medical Technology Industry In Figures,' [Online], [Retrieved December 27, 2016], http://www.medtecheurope.org/sites/defau lt/files/resource_items/files/ MEDTECH_FactFigures_ONLINE3.pdf.

35. Morden, T. (2016) Principles of Strategic Management, 3rd edition, Abingdon: Routledge.

36. Niazi, M.; Mahmood, S.; Alshayeb, M.; Qureshi, A. M.; Faisal, K. and Cerpa, N. (2016) 'Toward successful project management in global software development,' International
Journal of Project Management, Vol. 34, Issue 8, 1553-1567.

37. PMI (2013) A guide to the project management body of knowledge (PMBOK Guide), 5th edition, Project Management Institute, Pennsylvania: Newton Square.

38. Radar Group (2012) The Impact of Data Silos in IT Planning, White Paper, Winchester MA.

39. Rockart, J. F. (1979) 'Chief Executives Define Their Own Data Needs,' Harvard Business Review, Vol. 57, Issue 2, 81-92.

40.Santos, C.; Santos, V.; Tavares, A. and Varajão, J. (2014) 'Project Management success in health - the need of additional research in public health projects,' Procedia Technology, Vol. 16, 1080-1085.

41. Schönberger, M. (2014) 'Der professionelle Einstieg in die erfolgreiche App-Entwicklung,' In: Aichele, C. and Schönberger, M. (eds.) 'App4U. Mehrwerte durch Apps im B2B und B2C,' Wiesbaden: Springer, 87-132.

42.Stirling, C. and Shehata, A. (2016) 'Collaboration - The future of innovation for the medical device industry,' KPMG International Cooperative, [Online], [Retrieved January 17, 2017],

https://assets.kpmg.com/content/dam/kpm g/pdf/2016/05/the-future-of-innovationfor-the-medical.pdf.

43.Sumner, M.; Bock, D. and Giamartino, G. (2006) 'Exploring the linkage between the characteristics of IT project leaders and project success,' Information systems management, Vol. 23, Issue 4, 43-49.

44. Thurnes, C. M.; Zeihsel, F.; Visnepolschi, S. and Hallfell, F. (2015) 'Using TRIZ to invent failures -concept and application to go beyond traditional FMEA,' Procedia Engineering, 131, 426-450.

45.Vagelatos, A. and Sarivougioukas, J. (2001) 'Critical success factors for the introduction of a clinical information system,' Proceedings of IX Mediterranean Conference on Medical and Biological Engineering and Computing, 1055-1058.

46. Valeris, J. and Williams, B. S. (2016) '8 Healthcare trends that will transform medtech in 2016,' 19 January 2016, [Online], [Re-

Marius Schönberger and Andrejs Čirjevskis (2017), Journal of e-health Management, DOI: $10.5171 / 2017.956068$ 
trieved January 17, 2017], http://www.meddeviceonline.com/doc/heal thcare-trends-that-will-transform-medtechin-0001.

47.Wagner, E.; Scott, S. and Galliers, R. (2006) 'The creation of 'best practice' software: Myth, reality and ethics,' Information and Organization, Vol. 16, Issue 3, 251-275. 48. Wieczorrek, H. W. and Mertens, P. (2008) Management von IT-Projekten, 3rd edition, Berlin: Springer.

49. Wolf, T. (2015) 'Assessing the Criticality of IT Projects in a Portfolio Context using Centrality Measures,' Proceedings der 12. Internationalen
Tagung
Wirtschaftsinformatik (WI2015), March 4-6, Osnabrück, Germany, 706-721.

50. Xiangnan L.; Hong L. and Weijie, Y. (2010) 'Analysis failure factors for small \& medium softwareprojects based on PLS method,' The 2nd IEEE International Conference on Information Management and Engineering (ICIME), April 16-18, Chengdu, China, 676680.

51. Yew Wong, K. (2005) 'Critical success factors for implementing knowledge management in small and medium enterprises,' Industrial Management \& Data Systems, Vol. 105, No. 3, 261-279.

Marius Schönberger and Andrejs Čirjevskis (2017), Journal of e-health Management, 


\section{Appendix}

\begin{tabular}{|c|c|c|c|c|c|c|c|c|c|c|c|c|}
\hline No. & Success Factors & Author(s) & 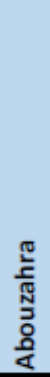 & 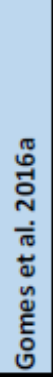 & 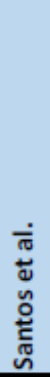 & 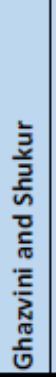 & 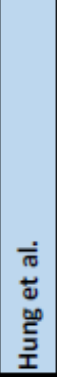 & 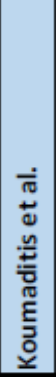 & 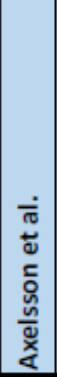 & 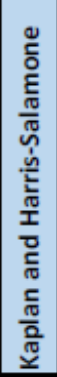 & 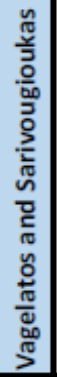 & $\begin{array}{l}\text { ㄸّㅇ } \\
\stackrel{\circ}{\circ}\end{array}$ \\
\hline & Clear goals / Scope & & $\mathrm{x}$ & $\mathrm{x}$ & $\mathrm{x}$ & & & $\mathrm{x}$ & & & $\mathrm{x}$ & 5 \\
\hline & Communication & & $\mathrm{x}$ & $\mathrm{x}$ & $\mathrm{x}$ & & & & & $\mathrm{x}$ & $\mathrm{x}$ & 5 \\
\hline & Complexity & & & & $\mathrm{x}$ & $\mathrm{x}$ & & $\mathrm{x}$ & & $\mathrm{x}$ & & 4 \\
\hline & Costs & & & $\mathrm{x}$ & $\mathrm{x}$ & & & $\mathrm{x}$ & & & & 3 \\
\hline & Culture & & & & $\mathrm{x}$ & & & $\mathrm{x}$ & & $\mathrm{x}$ & & 3 \\
\hline & Customer / User acceptance & & & & $\mathrm{x}$ & & & & & $\mathrm{x}$ & $\mathrm{x}$ & 3 \\
\hline & Customer consultation & & & & $\mathrm{x}$ & & & & & & & 1 \\
\hline & Enforce decision & & & & & & & $\mathrm{x}$ & & & & 1 \\
\hline 9 & Experience / Education & & & & & $\mathrm{x}$ & $\mathrm{x}$ & $\mathrm{x}$ & $\mathrm{x}$ & $\mathrm{x}$ & & 5 \\
\hline 10 & External experts & & & & $\mathrm{x}$ & & & & $\mathrm{x}$ & & $\mathrm{x}$ & 3 \\
\hline 11 & Governance & & & $\mathrm{x}$ & $\mathrm{x}$ & & & $\mathrm{x}$ & & & & 3 \\
\hline 12 & Information systems adjustment & & & & & & $\mathrm{x}$ & & & & $\mathrm{x}$ & 2 \\
\hline 13 & Maturity identification & & & $\mathrm{x}$ & $\mathrm{x}$ & & & $\mathrm{x}$ & & & & 3 \\
\hline 14 & Measurement / Controlling & & & & $\mathrm{x}$ & & & $\mathrm{x}$ & $\mathrm{x}$ & & & 2 \\
\hline 15 & Organisational change & & & $\mathrm{x}$ & & & & & & & $\mathrm{x}$ & 2 \\
\hline 16 & Organisational resistance & & & & $\mathrm{x}$ & & $\mathrm{x}$ & & & & & 2 \\
\hline 17 & \begin{tabular}{|l} 
Process alignment \\
\end{tabular} & & & $\mathrm{x}$ & & & $\mathrm{x}$ & $\mathrm{x}$ & $\mathrm{x}$ & & & 4 \\
\hline 18 & Project identification & & & $\mathrm{x}$ & $\mathrm{x}$ & & & $\mathrm{x}$ & & & & 3 \\
\hline 19 & Project planning / Long-term planning & & $\mathrm{x}$ & & $\mathrm{x}$ & & & $\mathrm{x}$ & $\mathrm{x}$ & & $\mathrm{x}$ & 5 \\
\hline 20 & Resources & & & $\mathrm{x}$ & $\mathrm{x}$ & & & $\mathrm{x}$ & & & & 3 \\
\hline 21 & Risk Management & & $\mathrm{x}$ & $\mathrm{x}$ & & $\mathrm{x}$ & & $\mathrm{x}$ & & $\mathrm{x}$ & & 5 \\
\hline 22 & Roadmap & & & & & & & $\mathrm{x}$ & & & & 1 \\
\hline 23 & Roles & & & $\mathrm{x}$ & $\mathrm{x}$ & & & $\mathrm{x}$ & $\mathrm{x}$ & & & 4 \\
\hline 24 & Security & & & & & $\mathrm{x}$ & & & & & & 1 \\
\hline 25 & Stakeholders engagement & & $\mathrm{x}$ & $\mathrm{x}$ & & & & & & $\mathrm{x}$ & & 3 \\
\hline 26 & Standards & & & & & & & $\mathrm{x}$ & & $\mathrm{x}$ & & 2 \\
\hline 27 & Team & & $\mathrm{x}$ & $\mathrm{x}$ & $\mathrm{x}$ & & $\mathrm{x}$ & $\mathrm{x}$ & $\mathrm{x}$ & & & 6 \\
\hline 28 & Technical tasks & & & & $\mathrm{x}$ & & & & & & $\mathrm{x}$ & 2 \\
\hline 29 & Testing & & & & & & & $\mathrm{x}$ & & & & 1 \\
\hline 30 & Time / Urgency & & & $\mathrm{x}$ & $\mathrm{x}$ & & & & & & & 2 \\
\hline 31 & Top management support & & & $\mathrm{x}$ & $\mathrm{x}$ & & $\mathrm{x}$ & & $\mathrm{x}$ & & & 4 \\
\hline 32 & Training Issues & & & & & & & & & $\mathrm{x}$ & $\mathrm{x}$ & 2 \\
\hline 33 & Troubleshooting & & & & $\mathrm{x}$ & & & & & & & 1 \\
\hline & & Total & 6 & 15 & 21 & 4 & 6 & 18 & 8 & 99 & \begin{tabular}{|l|}
9 \\
\end{tabular} & \\
\hline
\end{tabular}

\section{Appendix 1: Overview of critical success factors for IT/IS project implementation in the healthcare sector.}

Marius Schönberger and Andrejs Čirjevskis (2017), Journal of e-health Management, DOI: $10.5171 / 2017.956068$ 


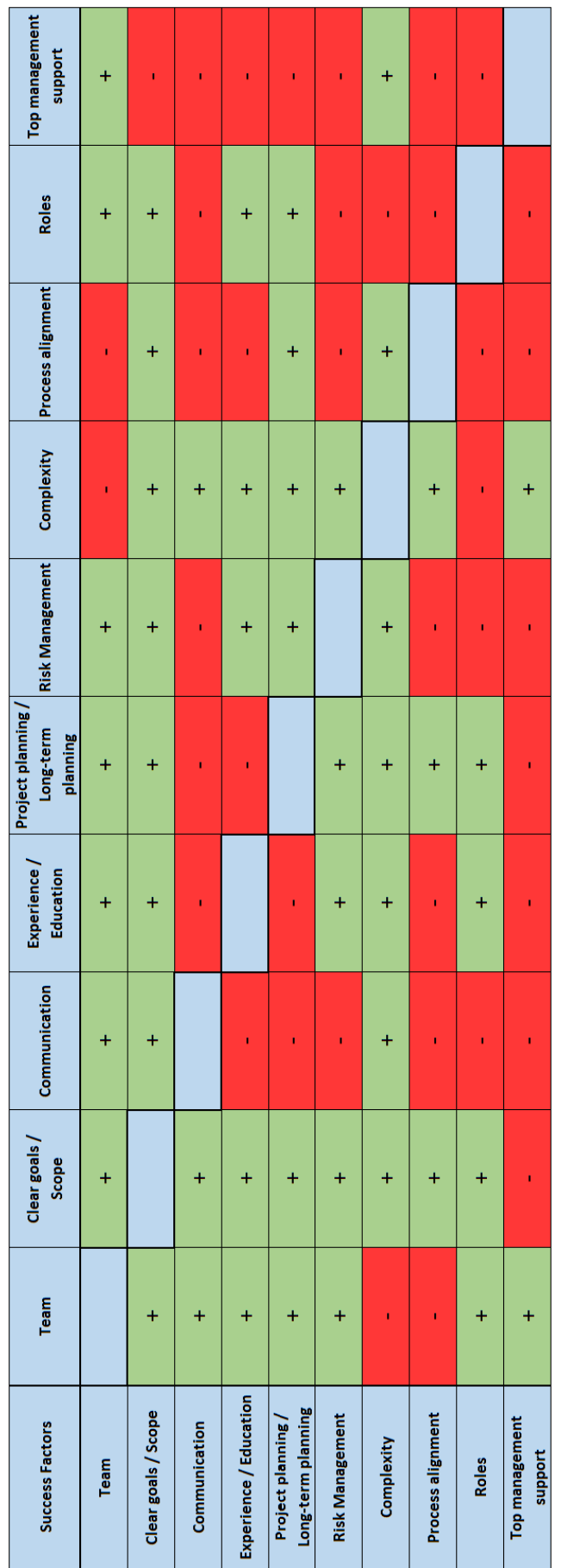

Appendix 2: Interaction matrix for the critical success factors for IT/IS project implementation in the healthcare sector. 